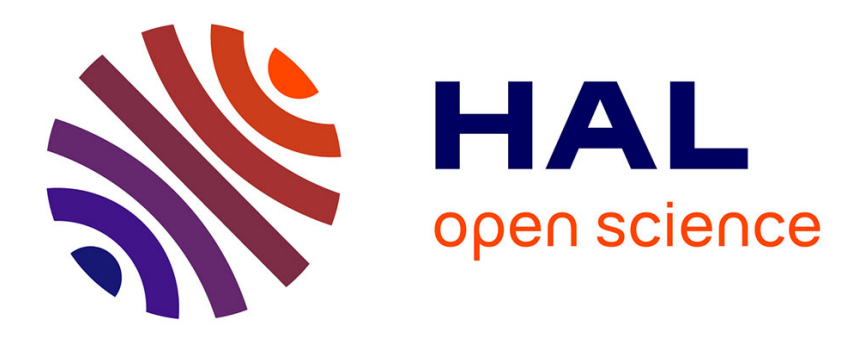

\title{
Ecology, diet, and social patterning in Old and New World primates
}

\author{
Claude Marcel Hladik
}

\section{To cite this version:}

Claude Marcel Hladik. Ecology, diet, and social patterning in Old and New World primates. Socioecology and psychology of primates, Mouton, The Hague, pp.3-35, 1975. hal-00561727

\section{HAL Id: hal-00561727 https://hal.science/hal-00561727}

Submitted on 10 Mar 2013

HAL is a multi-disciplinary open access archive for the deposit and dissemination of scientific research documents, whether they are published or not. The documents may come from teaching and research institutions in France or abroad, or from public or private research centers.
L'archive ouverte pluridisciplinaire HAL, est destinée au dépôt et à la diffusion de documents scientifiques de niveau recherche, publiés ou non, émanant des établissements d'enseignement et de recherche français ou étrangers, des laboratoires publics ou privés. 
HLADIK C.M. (1975) - Ecology, diet, and social patterning in Old and New World primates. In : R. H. TUTTLE (Ed.) Socioecology and psychology of primates. Mouton, The Hague : 3-35.

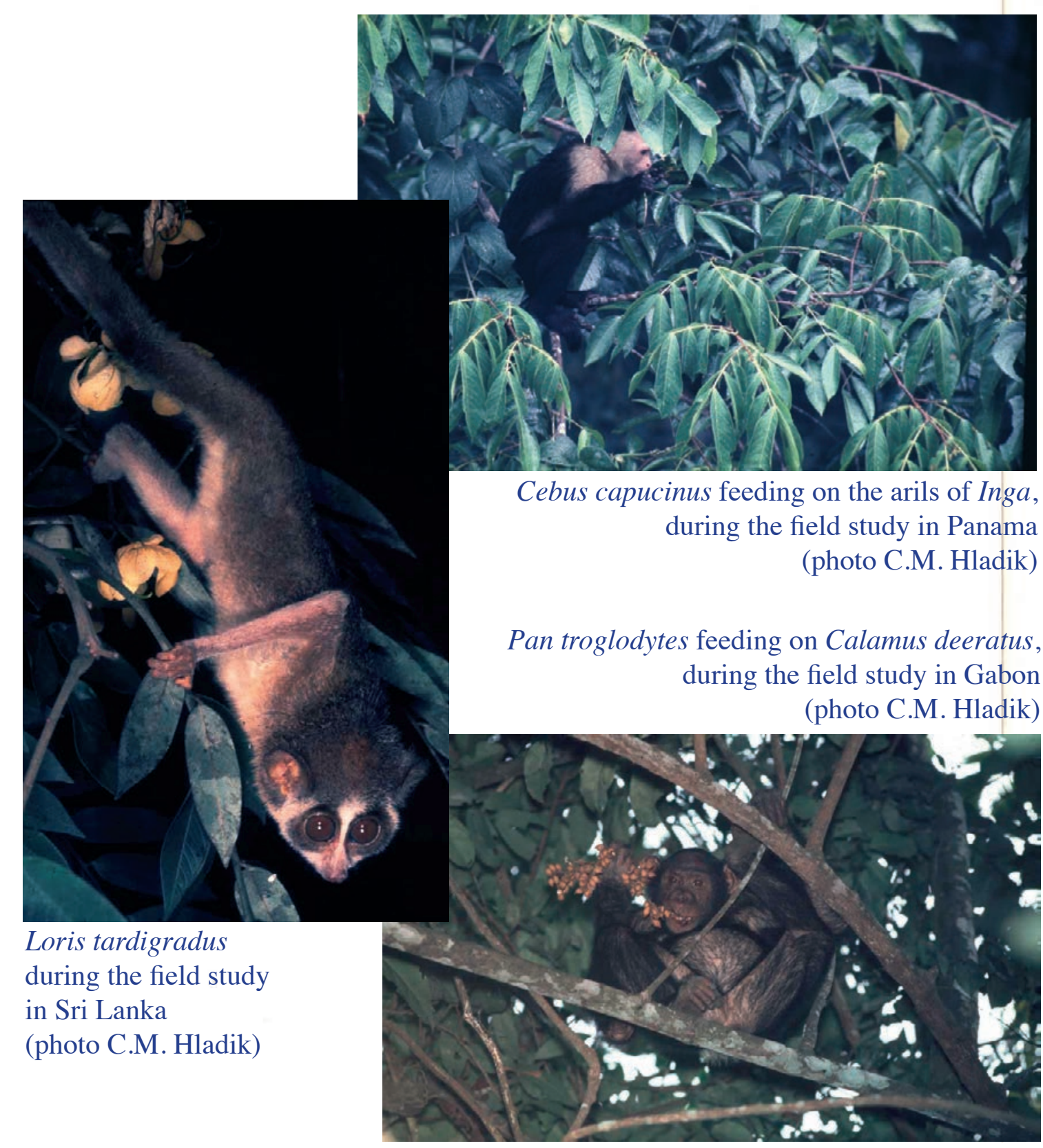

Ecology, Diet, and Social Patterning in Old and New World Primates

Specialization in primate species appears in various ecological niches. Eaters of repugnant insects (Perodicticus, Arctocebus, Loris) and tough leaf eaters (Lepilemur, Indri, Presbytis, Colobus) are the most clearcut examples. Among the many primate species that have differentiated in seventy-five million years, man is one of the less differentiated species from the ecological point of view. Consequently man is relatively more adaptable.

Some aspects of social structure are related to adaptation to ecological conditions. To demonstrate this, I will use the Ceylon primate population as an example that was studied in detail ${ }^{1}$ and about which we obtained the most accurate quantitative ecological data. Comparisons with similar ecological studies undertaken in Madagascar ${ }^{2}$ and in America (Barro Colorado) ${ }^{3}$ as well as in Africa (Gaboon) ${ }^{4}$ and consideration of numerous data collected by other investigators will allow us to see how far we can generalize a theory concerning the way the social patterning of the whole primate order is interdependent with environmental conditions.

I am indebted to Dr. Russell Tuttle for revising the English translation of this manuscript.

1 Smithsonian Biological Program in Ceylon, under the direction of Dr. J. F. Eisenberg.

2 Special concerns of Foreign Affairs (Paris), on the occasion of the International Conference of Tananarive, organized by Dr. J. J. Petter.

3 Smithsonian Tropical Research Institute, under the direction of Dr. M. H. Moynihan.

4 C. N. R. S. (France) Laboratory of Primatology and Equatorial Ecology, under the direction of Dr. A. Brosset. 


\section{ECOLOGICAL NICHES, FOOD AVAILABILITY AND ADAPTATIONS OF PRIMATE GROUPS AT THE POLON- NARUWA FIELD STATION, SRI LANKA (CEYLON)}

The Polonnaruwa field station is described in Hladik and Hladik (1972). We will mention here only some of its most important features. It is a semi-deciduous forest in the "dry zone" of Ceylon, where the annual rainfall is 1,700 millimeters. The very marked dry season is an important climatic factor considering that at the same latitude some moist evergreen forests do not have more rainfall.

The undergrowth of this forest has been cleared over a large area by archaeologists to bring to light ruins of a city of the twelfth century. In this area, which is very similar to the nearby forest (the canopy is intact except for vines), it was possible to observe in great detail the different species of primates, and to obtain good quantitative estimates of their natural diet (with control in the nearby forest). The whole area was surveyed and mapped, and we calculated the annual production of the different available foodstuffs. Using collecting baskets along a transection, a comparative estimate of the production in the primitive forest was made as a control.

Our field of detailed study covered 54.5 hectares, with a total length of two kilometers. Using an aerial photograph, all trees were mapped after ground identification. The canopy of each one of them was measured. Production was estimated from average measurements.

There are forty-seven species of trees. Though their spatial distribution is not uniform, it is interesting to consider it in relation to the use of the land and the foodstuffs by the different primate species.

Four primate species share the resources: two leaf monkeys of the same genus, Presbytis senex and P. entellus, one macaque, Macaca sinica, which chiefly uses the fruit resources, and a small nocturnal prosimian, Loris tardigradus, that can eat many sorts of repugnant insects.

Except for primates, mammalian fauna is fairly scarce at Polonnaruwa. There are no longer big predators (Panthera). Only the small nocturnal carnivores characteristic of the Ceylon dry zone (Eisenberg and McKay 1970), some rodents (two species of squirrels are often seen among the monkey groups), ruminants (Axis axis) and Tragulidae (Tragulus meminna) inhabit the area. Some cattle from a neighboring farm entered the undergrowth to feed on grass or shrubs but they did not interfere with the activity and feeding of the primates.

\section{Presbytis senex}

$P$. senex is a very unobtrusive species forming small groups of five to six individuals that always stay in the canopy (Plate 1). $P$. senex are not easy to observe. They hide their faces, move around a tree trunk or branch, and quickly flee. Our field station at Polonnaruwa is unique in that we were able to quantify diets by direct counting because of the clearance of undergrowth.

The yearly average of the diet of $P$. senex includes 60 percent leaves and shoots, 12 percent flowers and buds, and 28 percent fruits. Onehalf of this food is produced by only two tree species: Adina cordifolia and Schleichera oleosa from which fruits and flowers are eaten as well as shoots and mature leaves. The bulk of the food is obtained from no more than a dozen tree species; nevertheless Presbytis senex may eat small parts of many other trees.

The groups stayed in small territories that were three to four hectares wide (Rudran 1970, 1973; Manley f.c.). Shapes of the territories are shown in Figure 1. After mapping all trees at the field station, we were able to calculate the quantity of food available through the year for each of the groups (for details and methods of calculation, see Hladik and Hladik 1972).

Table 1 indicates the total food available per year for one monkey in each of the groups shown in Figure 1.

If we consider the spatial distribution of the food trees on the same scale as the home ranges, it seems fairly homogenous. The annual crop is about four tons of foliage (including an average of two tons of Adina) and about a hundred kilograms of Adina flower for a monkey

Table 1. Total food in kilograms (fresh weight) available per year for one monkey in each group in Figure 1

\begin{tabular}{|c|c|c|c|c|c|}
\hline & \multicolumn{2}{|c|}{ Adina cordifolia } & \multicolumn{2}{|c|}{ Schleichera oleosa } & \multirow{2}{*}{$\begin{array}{l}\text { Other trees } \\
\text { leaves }\end{array}$} \\
\hline & leaves & flowers & shoots & fruits & \\
\hline A & 1,300 & 60 & 240 & 65 & 1,100 \\
\hline B & 3,500 & 160 & 380 & 105 & 2,200 \\
\hline $\mathrm{C}$ & 2,100 & 100 & 420 & 115 & 2,200 \\
\hline D & 4,700 & 215 & 350 & 100 & 2,000 \\
\hline E & 3,500 & 160 & 510 & 160 & 2,000 \\
\hline $\mathrm{F}$ & 1,000 & 50 & 200 & 55 & 2,800 \\
\hline G & 6,500 & 300 & 300 & 85 & 5,800 \\
\hline $\mathrm{H}$ & 600 & 30 & 130 & 35 & 1,000 \\
\hline
\end{tabular}




\section{6 c. M. HLADIK}

whose annual needs are about 400 kilograms. Of course, the annual crop exceeds the annual need; but considering that the trees canno stay very long if they are totally defoliated at regular intervals, the ratio of food requirement to food available which is actually $1: 10$ can be considered as a maximum permissible for leaf eaters using a large amount of young shoots. In fact, for one of the groups (Plate 1 and $\mathrm{H}$ on Figure 1) the total annual crop was less than two tons. We noted that some trees in their territory were dying because the leaves and shoots were eaten too frequently. These animals lived in that restricted area because the male of the neighboring group ( $G$ in Figure 1) was very aggressive. Conversely, group $\mathrm{G}$ had more food available in its home range than others.

Thus behavior and social structure strongly affect spatial distribution of the species and consequently the habitat use and ecology.

Social structure (see Rudran 1970, 1973) allows division into small groups that use small portions of the field area (Figure 1). The dispersion of the tree species used by $P$. senex is homogenous enough in those small portions to allow a regular division. On the other hand, many other vegetal species are not so evenly spread, and they are important in food production for other primate species (see below).

Social units of $P$. senex are "one-male groups" that include a few females and their offspring. Some males are necessarily excluded from these basic groups and may stay solitary or form "all-male groups." In these units, individuals are less powerful; they are chased away by the leaders of the "one-male groups" and they live in places neglected by others and which are obviously not the best food-producing areas.

Direct fighting between two groups was not often observed. Contact at the borders of the territories was infrequent. The animals do not have to move very much to find abundant food. Powerful calls emitted by the males early at dawn can be considered as territorial calls. These calls come from the different groups responding to each other. In this manner all of them learn about the location of neighboring groups as soon as the period of activity begins.

Similar types of morning calls are known in other species of leafeating primates.

Other species of leaf monkey possess many additional features described for $P$. senex, viz. small groups (with a fairly similar social structure) that move only short distances in a small territory, the source of food always being a few common vegetal species distributed homogenously.

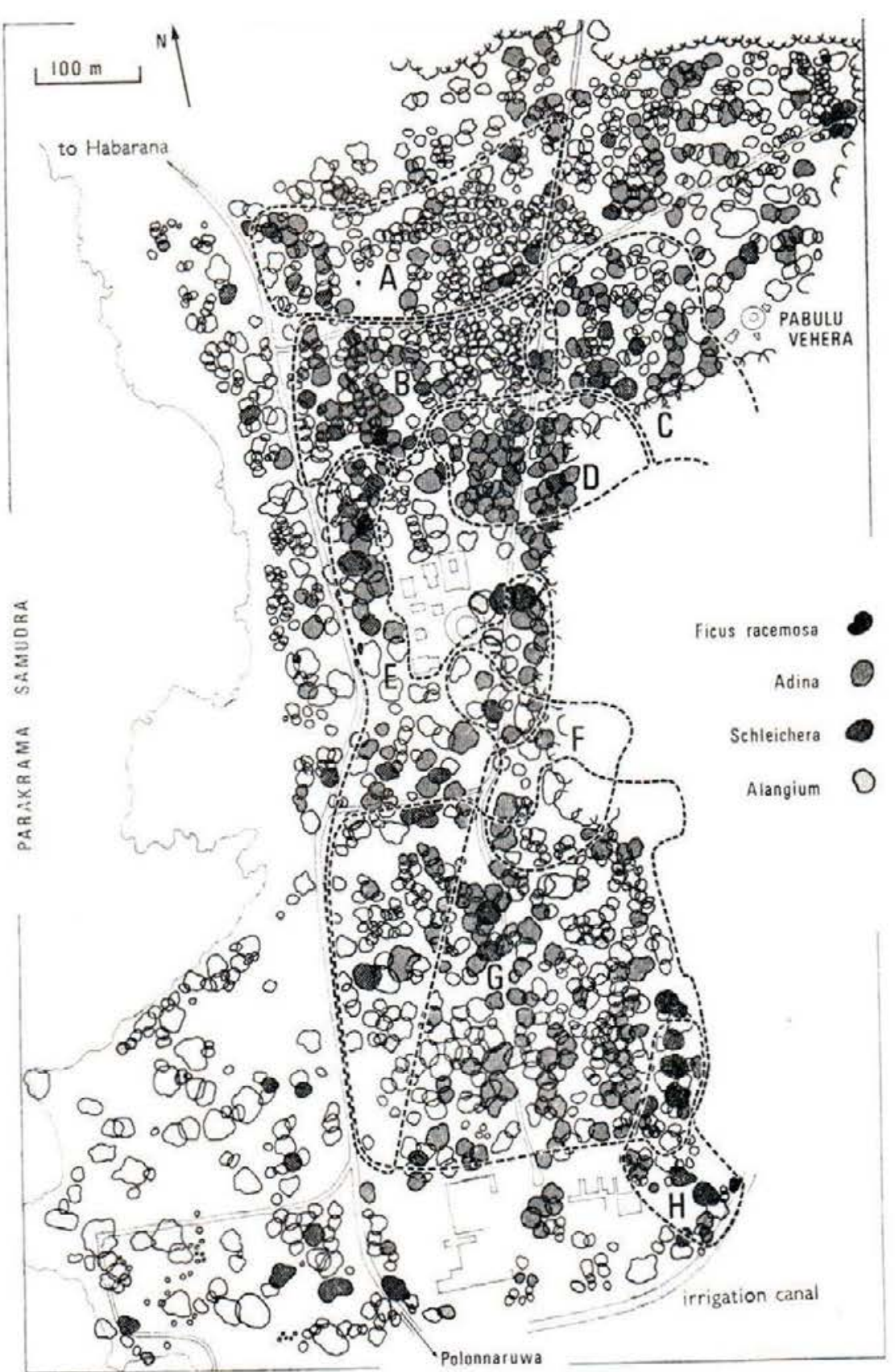

Figure 1. Acrial view of the field station at Polonnaruwa showing the canopy of in all trees. This open fown by dotted lines, Samudra). The limits of the home ranges $P$. senex are shomous disafter the data of Manley and Rudran. We note on this map the homogenous distribution of the main food species of P. senex: Adina cordifolia and Schleichera oleosa 


\section{Presbytis entellus}

It is noteworthy to compare the gray langur, $P$. entellus (Plate 2), of the Polonnaruwa field station because of noticeable interspecific differences in ecology and social structures.

These monkeys form rather large groups (twenty to thirty individuals), and they are very conspicuous because they come down to the ground and stay there for long periods of time without fear of man.

The home ranges of the different groups of $P$. entellus (Figure 2) were mapped mainly after Ripley's data. They are wider than those of the $P$. senex groups; nevertheless the biomass of $P$. entellus is remarkably similar (ten to fifteen kilograms per hectare) due to the large size of the groups. The total biomass of folivorous mammals is very high (twenty-five kilograms per hectare), probably reaching the maximum allowed by the available vegetation, and the maintenance of two rather similar primate species in ecological niches can be explained only by subtle differences in diet and habitat use.

The diet of the gray langur (considered as an average for a one-year cycle) includes 48 percent foliage, 7 percent flowers, and 45 percent fruits. Thus, this last item is eaten in larger quantities by $P$. entellus than $P$. senex. $P$. entellus uses foliage mainly in the form of tender shoots and flushings while $P$. senex includes more mature leaves.

P. entellus also eats some different food plants from those chosen by $P$. senex. But the main difference is in the larger number of food plants included in the diet of the gray langur. The main crops are: Walsura piscidia, Drypetes sepiaria, and the various Ficus forming the bulk (as Adina and Schleichera do in $P$. senex).

The food plants used by $P$. entellus are also more widely scattered in the field as is shown in Figure 2. Nevertheless, if we consider their spatial distribution in the home range, we see that it is fairly even. That is to say, in the territories of each group there is approximately the same number of each one of these food-producing tree species. If the territories were not so large (and the groups were smaller, yielding an identical population density) these tree species would not be so

Table 2. Annual mean production of trees for each individual living in the different territories shown in Figure 2

\begin{tabular}{llcccc}
\hline & Walsura & \multicolumn{2}{c}{ Drypetes sepiaria } & Ficus sp. & Schleichera \\
& shoots & shoots & fruits & fruits & fruits \\
North group & 40 & 180 & 23.5 & 62.5 & 30 \\
Central group & 20 & 135 & 20 & 262 & 115 \\
South group & (few) & $>50$ & $>10$ & 197 & 40 \\
\hline
\end{tabular}

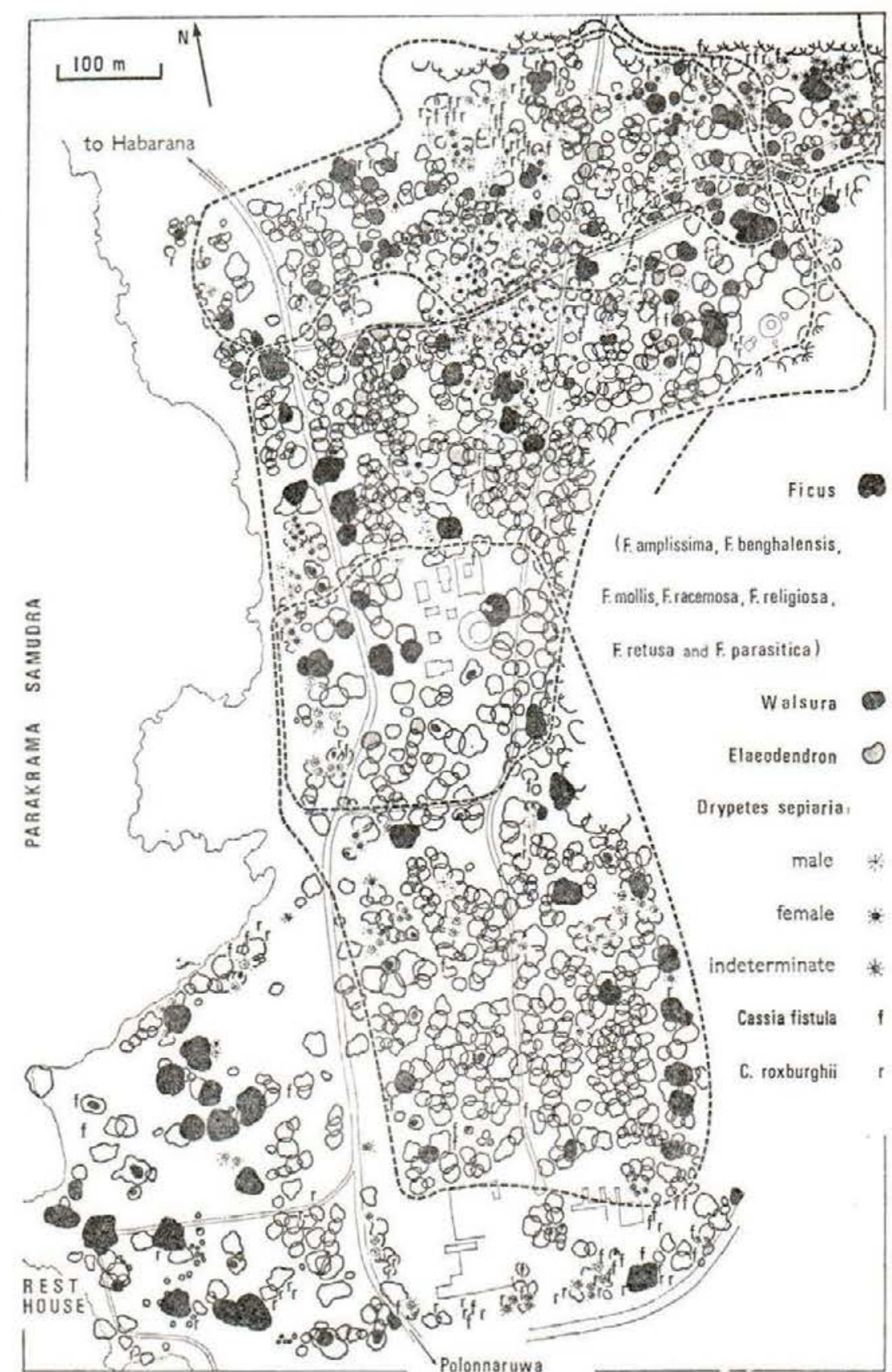

Figure 2. Map of Polonnaruwa showing the limits (in dotted lines) of the territories of three groups of Presbytis entellus, as for P. senex on Figure 1. Land use differs depending upon the scattering of food species in the field 
evenly distributed. Certain ones would be missing in certain territories and over-abundant in others.

For each individual living in the different territories shown in Figure 2 , there is an annual mean production calculated as shown in Table 2. An important food-producing tree, Drypetes sepiaria, which is concentrated in local spots on the general map is, nevertheless, equally distributed between the north and central groups. There are one female (producing fruits) and one and one-half male trees per individual (the data about the south group are not complete because the trees were counted after the fruiting season, but their distribution must be generally the same).

There are not too many Ficus in the home range of the north group. This group often tried to extend into the territory of the central group causing frequent battles between groups when the animals were feeding in Ficus near the boundaries.

Presbytis entellus feeds on a fairly large number of species. In Polonnaruwa, 90 percent of its food comes from twenty-three woody species. This total includes the twelve species used differently by the other Presbytis species. The gray langur uses other species for staple food, uses more fruits, and among leaves takes more shoots and tender leaves (27 percent of the total amount of food).

This greater selectivity in the diet is correlated with a slightly different general behavior and activity pattern. The group has to move more frequently and farther in the home range to find the different resources which are more widely dispersed. Some tree species have very short productive periods (for example the different Ficus species as well as the trees from which only young shoots are eaten). This is correlated with a social tradition in the group which permits using these different sources of food during seasonal cycles.

Nevertheless, the social structure of Preshytis entellus is quite loose. Jay (1965) characterized groups of langurs as peaceful and relaxed with very little intragroup aggression and no marked hierarchy. Adult males (mostly one dominant among adult males) protect the territory of their group against neighboring groups by chasing other males without really fighting (Ripley 1967). The results of such intertroop encounters in part determine the territorial boundaries.

In India, Sugiyama et al. (1965) observed smaller troops of $P$. entellus with only one adult male. Like $P$. senex "all-male groups" of $P$. entellus also occur.

This similarity in social structure of both species of Presbytis was observed at a lower level in our Polonnaruwa field station. In fact,
$P$. entellus were organized into large homogenous groups only during the dry season, and the larger groups lived in the most arid places: Jay (1965) found groups of 120 members in South India, and Ripley (1970) observed groups of sixty in Yala (southeast of Ceylon). The structure of the large groups is most effective as an anti-predator adaptation when the animals are on the ground. Many animals can watch and give alarm calls when a predator approaches, and females and young when fleeing can be protected by the more aggressive males who stay behind the group. Because, in the most arid zones, the gray langurs utilize water from water holes, the groups travel long distances on the ground (Beck and Tuttle 1972). In Polonnaruwa, they also seek water during the dry season and spend long periods on the ground to feed on the dried fruits of Drypetes and on the leaves of Mimosa pudica.

Conversely, during the monsoon season, the langur way of life is obviously more arboreal. The diet includes more foliage and more shoots (fruits are not so abundant) and the animals have to spend more time feeding in the canopy. At this time the groups often split into smaller units, and their social behavior tends to become more similar to that of $P$. senex. During the rainy season, $P$. entellus seems to be more disturbed by human observers, probably because it does not feel the reassuring presence of a large group. Like $P$. senex it uses a "spacing call" (morning whoop) that is not commonly heard during the dry season.

Thus the differences in social structure characterizing the two Ceylonese species of Presbytis are related to differences in ecology and habitat use and vary with these factors.

\section{Macaca sinica -}

The toque macaque (Macaca sinica) is ecologically very different from the two species of Presbytis. The social structure of its population differs markedly as well. I will now refer to certain observations that Dittus made at the Polonnaruwa field station (see Dittus, this volume). He followed several groups of macaques in large sections of the Polonnaruwa forest and observed variations in population structures over several years. Thus his primatological information is of exceptional value.

I will only cite some aspects of the ecology of the toque macaque in 


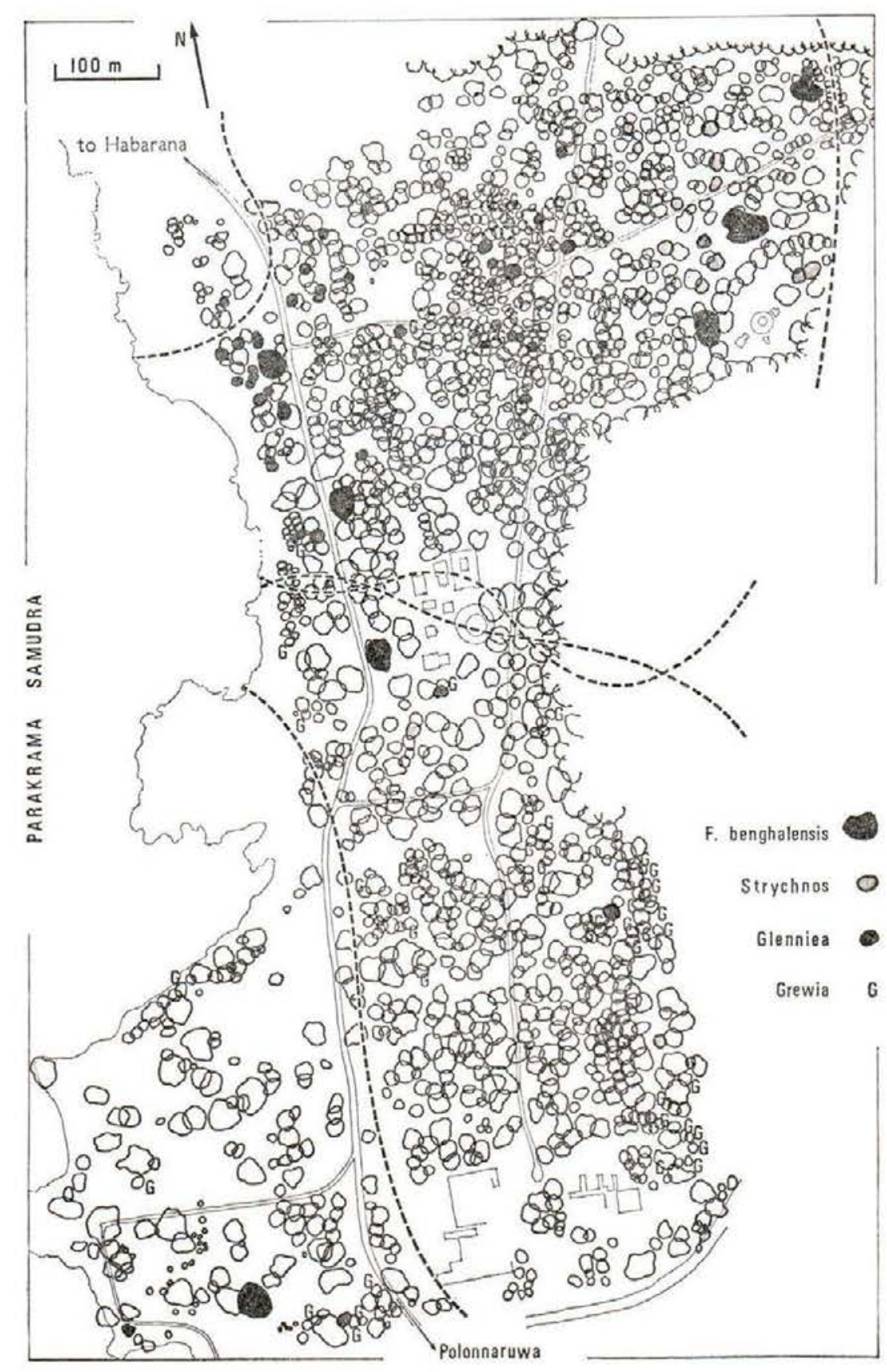

Figure 3. A view of the canopy of Polonnaruwa, as shown in Figures 1 and 2. The dotted lines are the limits of the home ranges of two groups of macaques. The vegetal food species shown as examples are very scattered order to clarify the most important ways in which it differs from other primates.

The diet of Macaca sinica is comprised chiefly of fruits (77 percent), with some green vegetal growth and flowers (14 percent) and a maximum of 5 percent fungae and 4 percent insects and small prey. The search for animal prey is the principal activity of the macaque. Because it is not abundant, the animals can get only very small quantities (according to Dittus the proportion can be even lower than our estimates). The fruit-eating primates must complement their diet with protein from animal prey and young vegetal shoots. They use many different species to compensate for the deficiencies in essential animo acids of the individual vegetal species (Hladik et al. 1971; 1973). Hence the toque macaque uses certain leaves and shoots like Strychnos potatorum and Randium dumetorum.

The fruits eaten come from many species widely dispersed in the field. The banyan, Ficus benghalensis, gives a fruit (which is eaten in large amounts) very rich in lipids, as do Schleichera oleosa, Grewia polygama, Glenniea unijuga, and Drypetes separia.

We can only make a general comparison of the distribution of these food-producing species (Figure 3 ) with what was accurately calculated for the leaf monkeys. Ficus benghalensis is more scattered in the field than any of the species used by the leaf monkeys and so are the other food trees utilized by the macaque. But their territories are very large. According to Dittus' observations, the two groups shown on our map (covering two kilometers) moved in a home range covering about twice the area described.

Despite the scattering of the main food trees, each group has very similar resources available because of the large size of its home range. In this perspective the dispersal of the important tree species seems to be "homogenous." But vegetal production is not an important factor, because it is very much greater than is the need - two tons of pulp of the fruit of Schleichera oleosa are available to the group located in the north on Figure 3 and the other species produce annually about one hundred times more than what is eaten (this also means that there is no competition with Presbytis entellus for fruits). In contrast, looking for prey means that the macaque must move in a very large home range, over irregular pathways to avoid destroying all of the game. The need for this is indicated by the fact that they actually obtain only a very small proportion of their food in animal proteins (compared with other primates of similar weight such as Cebus, which feeds on fruits, insects, and a few leaves). 
The two groups of macaques which we studied included only twelve and thirteen individuals. Their territories were thirty and forty-five hectares, respectively. (Actually, we must consider their "area of land use" as equivalent to twenty-five and thirty hectares because there were partial territorial superpositions.) The biomass is two and onehalf kilograms per hectare. This is the highest figure for primates at this trophic level.

The intragroup social organization is a linear hierarchy evident among males but not so marked for females. This organization allows a close integration of individuals, each with a precise role to play, and greater general efficiency when foraging or detecting predators because most of the time is spent on the ground.

This social model is common to many primate species with similar ecological background. The diet including small prey has the same effect on habitat use. It necessitates long journeys, sometimes on the ground, over a very wide territory.

\section{Loris tardigradus}

The slender loris, Loris tardigradus, also uses a portion of the animal resources of the Polonnaruwa forest.

We cannot compare social structures among such nocturnal Prosimiae to what we saw in the group of higher primates described above. Nevertheless, it is useful to examine a few examples to try to under stand how these primates with complex social structures may have evolved.

The slender loris comes from a branch that might be very close to the most primitive primate ancestor. Its exclusively insectivorous diet is composed of small prey found along branches and vines on which the loris moves very slowly in order to detect by smelling (Petter and Hladik 1970). It is likely that the persistence of this primitive form is due to its nocturnal cycle of activity, slow movements which make it unobtrusive and very specialized diet, which consists of repugnant insects, myriapods, and ants - which are neglected by other mammals.

We generally observed single lorises. The species is designated "solitary"; but this does not mean that there are no social contacts between the individuals of a population.

We located the individual home ranges in a population at Polonnaruwa (Figure 4) during a brief field study with Petter, on the edge of a secondary growth forest. The area used by one adult male or

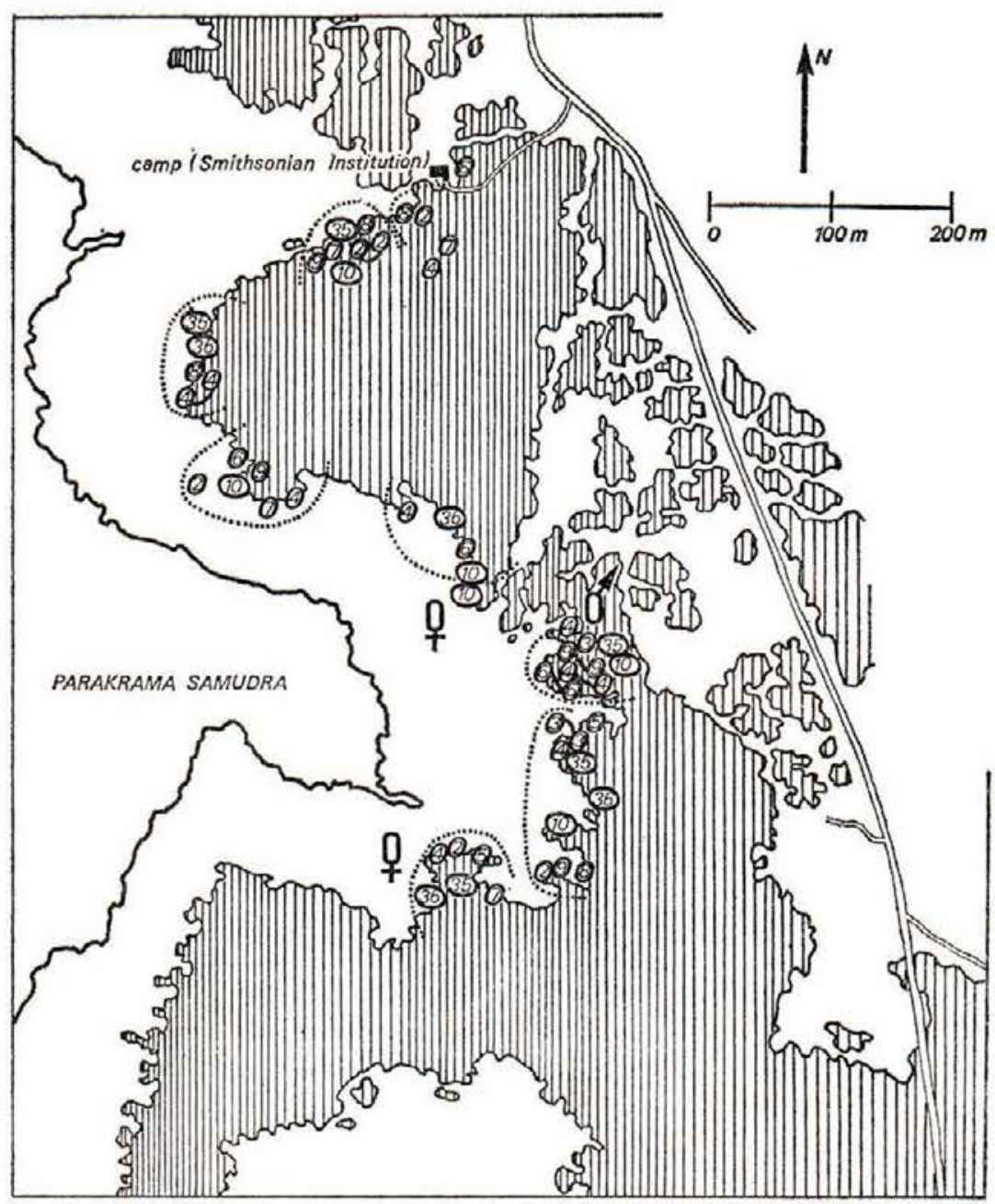

Figure 4. Some home ranges in a population of Loris tardigradus at Polonnaruwa. The area depicted here is to the south of that shown in Figs. 1, 2, and 3. Each circled number indicates an observation in December, 1969. Home ranges are shown by dotted lines

female was about one hectare. Calculation of the corresponding biomass gives a fairly high weight for a secondary or tertiary consumer, 0.25 kilograms per hectare.

Social bonds among scattered individuals of this population probably correspond to what was described by Charles-Dominique $(1971,1972)$ for African Lorisidae: that is, one male individual territory is partially 
superimposed on one or several individual female territories. This type of primitive social structure is illustrated by the example of Lepilemur described below.

\section{ECOLOGICAL NICHES AND SOCIAL STRUCTURES OF MALAGASY LEMURS}

Along the banks of the Mandrare River, in the south of Madagascar, is a gallery forest very similar to the Polonnaruwa forest. Five species of lemurs occur in this gallery forest. Lepilemur leucopus, Cheirogaleus medius and Microcebus murinus are small nocturnal species. Propithecus verreauxi and Lemur catta are larger diurnal species.

There are similarities between the social organizations of these lemur populations and what was observed, in similar conditions, among the more evolved monkeys of Ceylon. From these similarities we can get an idea about the evolution of social groups of primates.

\section{Lepilemur and Other Nocturnal Forms}

The most primitive social organization was observed in the sportive lemur (Plate 3) (Charles-Dominique and Hladik 1971).

Individual territories observed in the field are shown in Figure 5. This type of social patterning corresponds to what was described for many other "solitary" primitive mammals. Each female protects its territory against other females but will share it for one or two years with one or several daughters. The male has a wider territory extended over one or several female territories and protects it against other males. As a result of this organization some extra males live outside of the population nucleus (peripheral males).

The most important part of the nocturnal activity of these animals is a motionless watching at the border of the territory. At the beginning of the night, Lepilemur makes some specific calls. By these sounds it clearly shows the neighboring animals what its location is at the moment. It is likely that the few animals living nearby are able to identify the sportive lemurs individually by their calls (differing slightly from one animal to another).

The food of Lepilemur is very abundant in all parts of the territory,

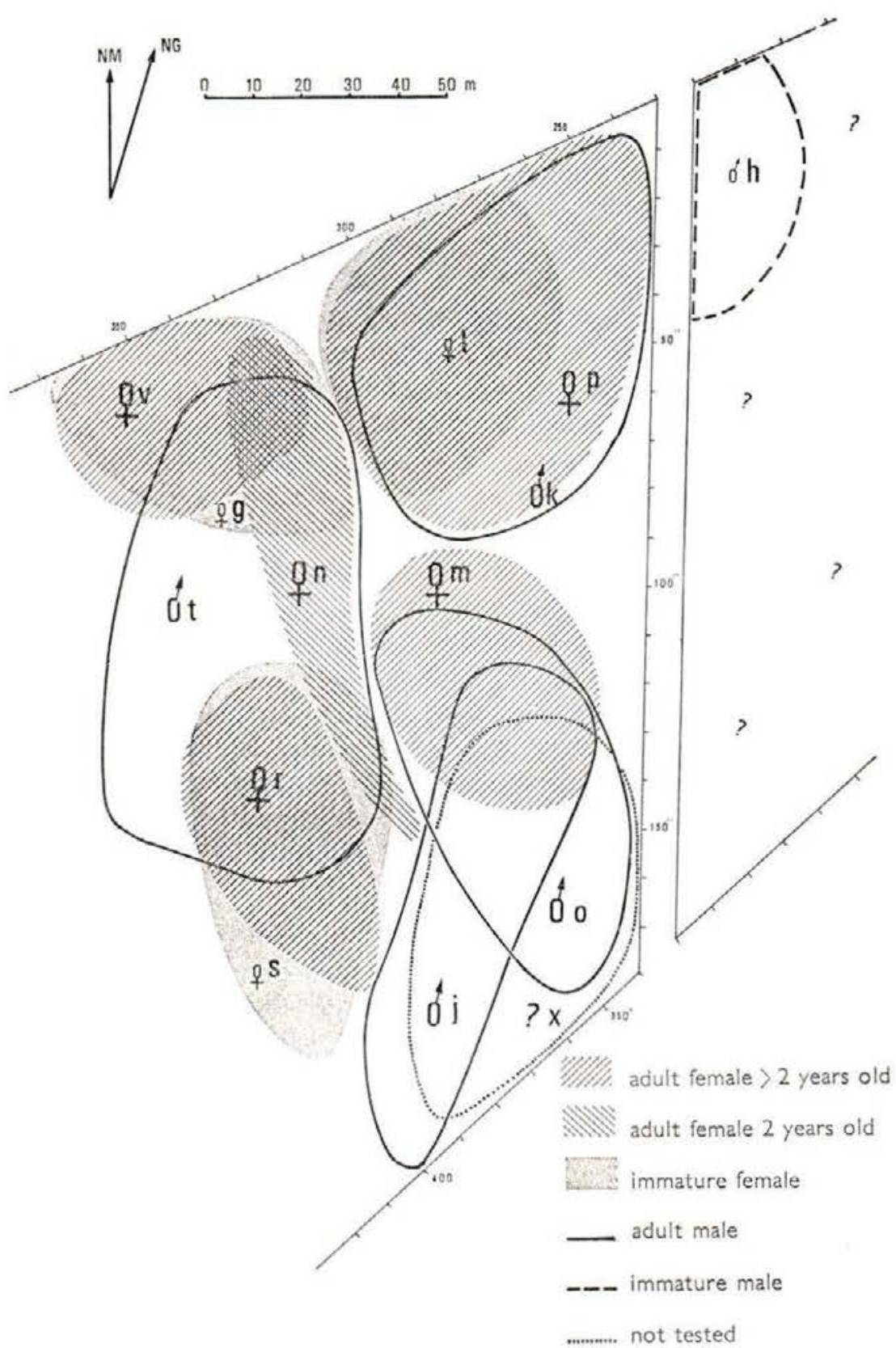

Figure 5. The individual territories in a population of Lepilemur leucopus, in southern Madagascar. Territories of adult males cover territories of one or several females. The adult females are tolerant toward their daughters (territory in grey). 
consisting chiefly of common foliage and flowers. This explains why the animals do not move much and why they spend most of their time watching competitors at the territorial boundaries.

This activity of territorial defense is complementary to the feeding activity. We demonstrated that during a short period the individual territory contains only 1.6 times the minimum amount of necessary food. Thus the surface area of the territories has been selected by this periodic limiting factor. As in the examples previously shown, the population density is precisely adjusted, through social and behavioral patterns, to the maximum available resources.

In the gallery forest, the biomass of Lepilemur reaches five kilograms per hectare (810 animals per square kilometer). We must consider, in the ecological system, a necessary balance between folivorous nocturnal lemurs and the larger diurnal forms that are also partly folivorous. Thus, the total size of folivorous biomass in this forest of Madagascar is almost similar to what we observed in the same type of forest at Polonnaruwa.

The Loris in Ceylon has a biomass twenty times lower than the biomass of Lepilemur. This difference is due to the differences in trophic level of the two species. The Loris only uses animal food. It is a secondary or third consumer in the trophic chain. This type of food is ten to one hundred times less abundant than vegetal food.

Yet social structures are very similar ${ }^{5}$ in Loris and Lepilemur despite the very important differences in their ecologies. For both species, it seems most probable that this organization does not differ very much from that of the primates at the beginning of their evolution. Each of them, at the beginning of the process of differentiation, has become adapted to a highly specialized ecological niche. And so, from the beginning of the Tertiary era they maintained their morphological form as well as their social traditions. Like Tamiasciurus (Smith 1968) their population densities are adjusted to food availability only by the system of individual territories. But their social structures are already more sophisticated. The males have permanent contacts with one or several females for whom they "control" territories.

Other nocturnal lemurs, for example the mouse lemur Microcebus (Martin 1972), have similar social structures but with a higher level of gregariousness: several animals might gather in a common nest or hollow tree trunk for the daily rest. From an ecological point of view, they are less specialized than the animals described above, eating insects,

5 The exact social structure of the Loris population is still to be studied. fruits, gums, and foliage. We do not have precise information about all the different species of Microcebus but it is certain that they are transitional forms between Loris and Lepilemur which possess a primitive type of social structure.

\section{Diurnal Lemurs Forming Structured Groups}

The ecology and type of habitat use of the sifaka (Propithecus verreauxi) and the ring-tailed lemur (Lemur catta) is so reminiscent of the two species of Presbytis in Ceylon that we may consider them as an experimental model. Two groups of primates evolved separately in Ceylon and in Madagascar. Similar environmental conditions gave rise to partly similar social structures. Thus the social forms found in Madagascar must not differ much from the organization in the first groups of true monkeys.

Groups of sifakas are small, barely mobile units in a small territory. For instance, one group of three sifakas lived in one hectare (Petter 1962). Sifakas feed on leaves and fruits but their diet is less folivorous than the diet of Presbytis senex in Ceylon. The social units (Petter et al. i.p.) are "family groups" (in the usual Western meaning of the "family"), including only one couple and their offspring. The sifakas are concentrated a little higher in the gallery forest along the Mandrare River (Jolly 1966). In larger groups (four to six) there is more tolerance among males and among females (Sussman and Richard 1974). Indris (Indri indri) are more similar to the Presbytis senex, with a highly folivorous diet, but they live only in the moist forest of the eastern coast of Madagascar. They also form social units with only one couple (Petter i.p.). This can be considered as the most primitive type of group.

Groups of ring-tailed lemurs are larger, including twenty to thirty individuals (Jolly 1966). This recalls the groups of Presbytis entellus of Ceylon. Like these monkeys, ring-tailed lemurs eat leaves and fruits from many species. They often move on the ground over a fairly large territory. There is a hierarchy, with ranks of dominance among males and females. This linear hierarchy is an important factor in group adaptation to environmental conditions. It allows the presence of several males without loss of their aggressiveness, and thus better protection against predators for the whole group when it is moving on the ground, which is an essential aspect of searching out certain types of food distributed over the territory. 
Sussman (1974) compared the Lemur catta with Lemur fulvus in Malagasy forests where both species occur. Lemur fulvus has a less sophisticated diet (three vegetal species yielded 80 percent of the food) and eats more leaves than $L$. catta. Comparing the diet and social organization of Lemur fulvus to those of Presbytis senex in Polonnaruwa, it is remarkable how similar they are. Lemur fulvus live in small groups without much hierarchy and remain in very narrow territories (Sussman 1974). The biomass may reach twenty-five kilograms per hectare like $P$. senex.

In these few examples of Malagasy lemurs, we note the great possibilities for variation of social structures but mostly for the diurnal species. The "solitary" mode of the nocturnal species is really a prototype of matriarchal society because the young are associated with their mother and share her territory during at least a short period. In the family groups, for instance among Indriidae, the male remains in permanent contact with one female. According to the environmental conditions, there may be some tolerance among adult males or females in wider groups. In more gregarious species of lemurs we observe instances where there is more tolerance among males or among females.

An intermediate social form between the "family group" and the multi-males group might be found in Hapalemur griseus (Petter et al. i.p.). These are small diurnal lemurs that live on the bamboos in swamp areas. They are tolerant enough to form small groups adapted to permanent guarding against dangerous predators like Galidia. The evolution of contact calls and alarm calls should also be considered as a criterion of adaptation to a hostile environment.

Identical variations in social patterning are found in lemurs and monkeys. In most cases closely similar ecological adaptations require the same type of social structure. Thus we can assume that the actual structures ("family groups") in the less specialized species of lemurs are the best representation of what was the intermediate social condition in the diverse phylogenetic radiations of the Old and New World monkeys.

ECOLOGY AND EVOLUTION OF THE SOCIAL ORGANIZATION IN THE NEW WORLD MONKEYS

The common ancestors of the primates were geographically separated at an early stage and, in the New World, they evolved towards many forms of the Platyrrhini. To exemplify these forms, I will refer to our observations between 1966 and 1968 on Barro Colorado Island (Panama). Determination of types and quantity of food available for each species will give an idea of its way of adaptation to the environment (Hladik and Hladik 1969).

Barro Colorado is a tropical rain forest. Most of the primate species live in this type of forest. Unlike areas discussed earlier it is not possible to get as precise quantitative data in rain forests. Ecological niches in a rain forest are generally more specialized because there are more animal and vegetal species.

On Barro Colorado Island there are still areas with young vegetation but most of it is mature forest. The dry season is marked by intensive sun radiation (no mist or clouds as in equatorial zones), and many trees defoliate at this time. It is semi-deciduous moist forest differing from the evergreen forest of the equatorial zone.

Five species of primates share the resources of this forest with specializations as in the examples of Ceylon and Madagascar. If we consider the ecological similarities and differences, the social patterning is found to be modeled in a series of similar types.

\section{Alouatta palliata}

The howler monkey, Alouatta palliata (Plate 4) is well known through the ethoecological studies of Carpenter. The groups include ten to twenty individuals. The howlers always stay in the upper canopy. They are the most folivorous among New World monkeys. But their diet is not markedly similar to the diet of Presbytis in Ceylon. The diet of Alouatta consists of 60 percent fruits and only 40 percent leaves. The ecological niche of the true folivores, in Barro Colorado, is filled by two species of sloth (Bradypus and Choloepus) which constitute the most important part of the biomass (Eisenberg et al. 1972).

With a group of ten howlers using fifteen to twenty hectares of forest, the biomass comes to a maximum of four kilograms per hectare. The howler consumes a fairly small number of vegetal species, especially several kinds of Ficus from which it can eat immature fruits as well as leaves. The groups do not move much because the food is easy to find in most parts of the territory. The well known call is equivalent to the morning call of other leaf-eating primates. It evidences presence in their territory without moving. 
The distribution of the vegetal species used as food (Figure 6) is not as homogenous as it is in Polonnaruwa. This explains the need for a larger territory (as for the frugivores) to include enough of each kind of food tree. Consequently for the same density of the population groups will be larger than the "one-male group."

The concept of the "age-graded male troop," introduced by Eisenberg, Muckenhirn, and Rudran (1972) fits this case. According to these authors, howlers have the "one-male group" structure when the population density is low. When the density increases, several mature males may coexist in the same group. This situation corresponds to what was shown for the frugivorous-folivorous lemurs of Madagascar with the difference that, among lemurs, females are generally the less tolerant and the system is closer to a matriarchy.

In howler groups, cohesion is due to the tolerance between males. Nevertheless they might be chased away by the dominant male when they reach sexual maturity. According to population density they may become peripheral males or solitary.

\section{Ateles geoffroyi}

The red spider monkey, Ateles geoffroyi, was reintroduced on Barro Colorado by Moynihan. The nucleus of the population (six individuals in 1967) had a home range of forty hectares that is supposed to be adjusted to available food. Their biomass was about one kilogram per hectare.

Ateles is typically a frugivorous monkey. Its diet includes 80 percent fruits, is complemented by shoots and young leaves ( 20 percent) and a very small quantity of animal prey (less than 1 percent). Many species of fruits are used. So, ecologically, Ateles differs from Aloutta as much as $P$. senex differs from $P$. entellus. But the two Panamanian primate species, both frugivorous, are in a higher trophic level (with a lower biomass).

A great tolerance between individuals allows the formation of large troops of spider monkeys that can split into small units. These subgroups are organized around the females and their offspring (Eisenberg and Kuehn 1966) but the general shape of the social organization is the "age-graded male group."

Cebus capucinus

The white-throated capuchins (Cebus capucinus) are organized in more
A
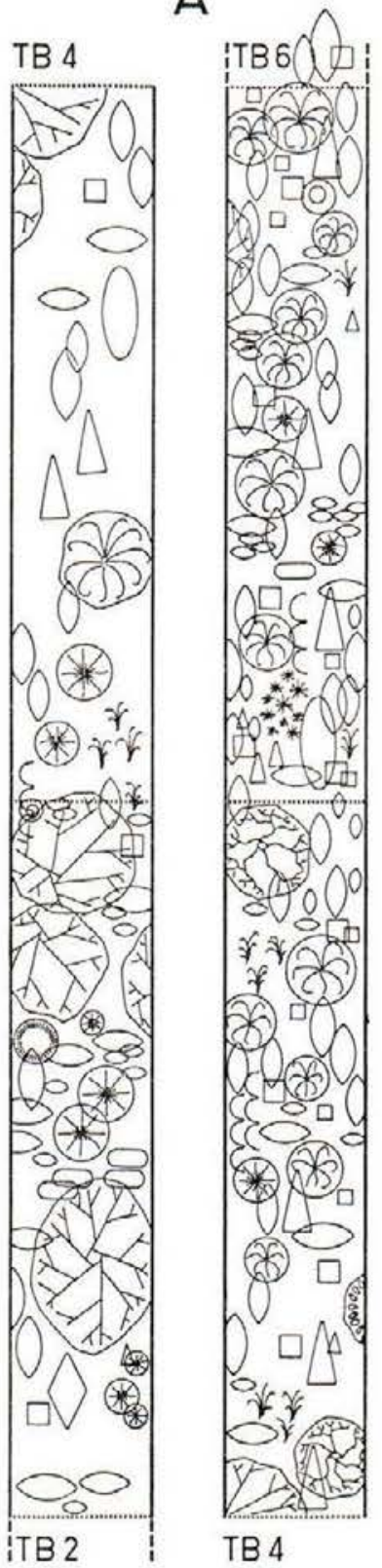

B

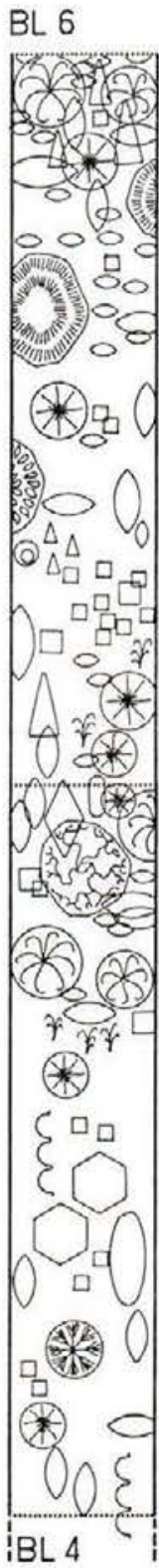

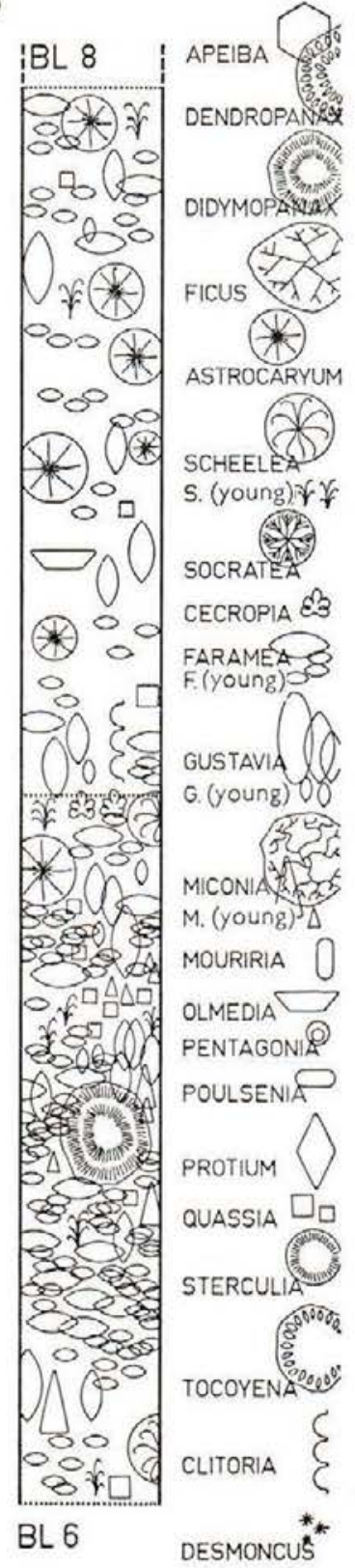

Figure 6. Distribution of some food species used by the primates of Barro Colorado, mapped on two transections, twenty meters wide, crossing the home range of the different groups (see comments in the text) 
structured groups over wide territories. One group whose feeding behavior we observed was made up of fourteen Cebus moving over a territory of ninety hectares (Oppenheimer 1968). As with the macaque, the chief activity of the capuchin is foraging for small prey (insects, spiders, and other invertebrates) found in hollow trunks or dead leaves (mostly on the ground, in the litter). This predatory behavior also involves long irregularly patterned walks over a large home range. Furthermore, the animals have to spread out when moving and keep contact by specific calls.

The diet of the capuchin includes 65 percent fruits, 20 percent animal prey, and 15 percent shoots, leaves, and stems. The maximum number of prey they can get in the forest litter is only a small fraction of the total amount they need. Therefore they are forced to be frugivores. We note that they get many more insects than the macaque in Ceylon do, and correlatively, their biomass is much smaller ( 0.5 kilograms per hectare). Thus they do not need a higher quantity of animal food per hectare.

If fruits are the main food of the capuchin, they are, nevertheless, selected in a particular way in relation to their chemical composition (Hladik et al. 1971). Cebus will select many fruits rich in lipids. For instance, among different palm trees it will take the fruits of Scheelea zonensis. (Conversely, the spider monkey will choose Astrocaryum standleyanum which gives more glucids.) In Figure 6, we note the abundance and rather even distribution of the Astrocaryum palm tree compared to the more scattered Scheelea palm tree. Again there is a correlation with the size of the territory, which is larger for the primate using the more scattered food-producing species. As among Ceylon primates this demonstrates the way the social structure adapts to an homogenous distribution of available food.

There is a linear hierarchy among female and male capuchins. But males of the age-class of four to five years are generally chased away (Oppenheimer 1968) showing a tendency towards the social type of "age-graded male group" (Eisenberg et al. 1972). Integration of individuals in a group of capuchins is accomplished through social exchanges like allogrooming. Grooming is more frequent in this species because it is necessary for animals that spend much time foraging in litter and dead wood to clean their fur. Some types of ritualized behavior such as the aggressive display and various ritualized responses permit the avoidance of true fights, and yet preserve a high level of aggressiveness in a group which is exposed to predators.

\section{Saguinus geoffroyi}

The feeding behavior of the rufus-naped tamarin, Saguinus geoffroyi, does not differ very much from that of the capuchin, although the diet is much more insectivorous. The tamarin is smaller than the capuchin and thus it needs less food. In the same environment it captures about the same number of small prey, so the relative proportion is higher. Its average diet is 60 percent fruits, 30 percent insects, and 10 percent green parts of vegetation.

The tamarin is becoming rare on Barro Colorado Island, probably because it is specifically adapted to the edge of the forest and to the secondary growth. It lives in thick vegetation and rarely comes down to the ground. Social units are groups of six to nine individuals (Moynihan 1968) including one or several pairs of adults and their offspring.

So, among the Callithricidae (marmosets and tamarins) which are the most primitive radiations of the New World primates, we already find a sophisticated social pattern. But in most of the genera, the groups are of the "parental type" (Eisenberg et al. 1972), which corresponds to Petter's "family type." In such groups, an adult pair lives with permanent bonds, reinforced by social exchanges like grooming and bodily contacts.

\section{Aotus trivirgatus}

The night monkey, Aotus trivirgatus, is a unique example of a true monkey adapted to a nocturnal cycle of activity. On Barro Colorado Island it lives either alone or in a small primitive group including at most one adult pair and one or two infants (Moynihan 1964). Aotus is among the least gregarious species of primates: there is no ritualized display as in the social species, which serves to divert direct fighting between individuals.

We have no precise ecological data about the night monkey, thus it is difficult to make comparisons with other species. It does not seem very specialized in its diet. It may be like some transitional forms of lemurs.

\section{ECOLOGICAL COMPARISON: PANAMA VS. CEYLON}

I will now draw a parallel between the precise ecological data on the Ceylon primates and those just described for the species of Barro Colorado. In Figure 7b I show a division into more specialized ecological 
niches in the rain forest. In the dry forest of Ceylon, the primate species are less specialized in their diet. Hence all of them cover the whole available food supply (from the insectivores to the more specialized folivores). In the rain forest of Barro Colorado they have to share the resources with other mammalian species. So, in Figure $7 b$, they are gathered in a narrower space according to their biomass which depends directly on the trophic level, i.e. the type of diet. Similar comparisons could be made with the primate species in Madagascar or in continental Africa but the ecological data are not yet accurate enough.

For a given species, the groups are more or less important not only in relation to their biomass and available food but also according to particular conditions of the environment (for example scattering of vegetal food species). The cohesion of large groups is due to the emergence of ritualized displays that make possible tolerance between the adults, male or female.

It is not possible to say whether ethological evolution of the social structures came from particular pressures of ecological conditions or if the adaptation to the environment followed these socioecological changes. What is certain is that correlation between those two conditions allows the survival of the different species.

\section{SOCIAL LIFE AND ECOLOGY IN ANTHROPOID APES}

A parallel evolution took place in the forests of the Old World, and there are many examples of convergences in socioecological adaptations rather similar to those shown in our examples (Struhsaker 1969). But there is no place where ecological data have been collected in much detail.

We studied Pan troglodytes troglodytes in the forest of Gaboon for one year (Hladik 1973).

The chimpanzee is a true frugivore which complements its diet with green plants and a few insects or other invertebrates $(68$ percent fruits, 28 percent leaves and bark, 4 percent insects; see Figure $7 \mathrm{a})$. Occasionally it eats small game animals. This particular predatory behavior is very interesting to consider in itself (Goodall 1965; Teleki 1973) but it has no true consequences for nutritional needs because the average quantity of meat eaten is very low. Furthermore this type of food is used only by adult males and a few females; the juveniles, whose protein needs are the highest, have no access to the meat.

This hunting and meat-eating behavior could be compared with what is known about primitive human tribes of hunter-gatherers. For them, meat-eating is a pleasure as well as an opportunity to organize festivities with social exchanges. But precise ecological data show that their diet is almost entirely vegetarian ( 80 percent fruits and roots collected by women; Woodburn 1968). In human populations, the meat of the game is a significant source of proteins, but it is not a compulsory need considering that some kinds of insects are included in the food gathered by women (e.g. caterpillars are richer in proteins and lipids than meat).

In the diet of the chimpanzee the proportion of animal food as well as the fruits and other vegetal parts may vary from one place to another. This is not surprising if we consider that the geographical range

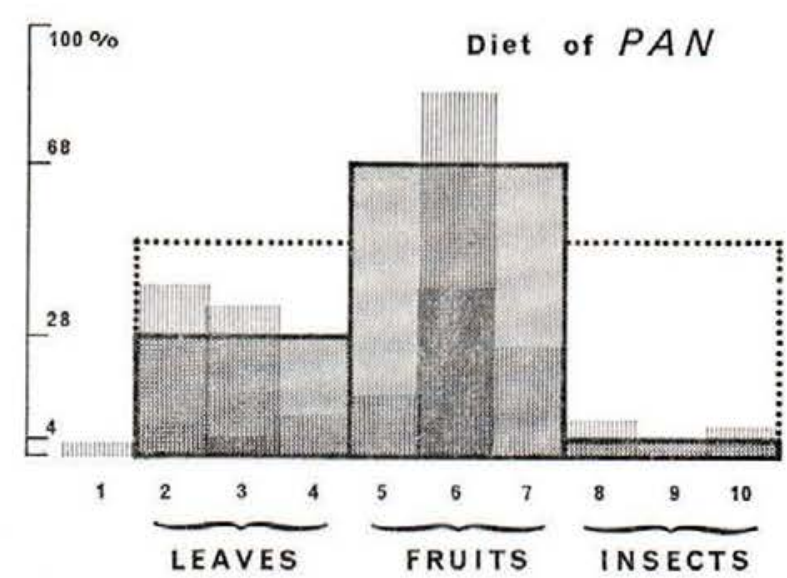

Figure 7a. Example of the diet of the chimpanzee (Pan troglodytes troglodytes). This diagram is made with the same symbols as those used for the diets of other primates in Figure $7 \mathrm{~b}$.

Each of the grey parts of the three squares is proportional to the corresponding type of food ingested in a year:

Leaves ( 28 percent), in the left square;

Fruits (68 percent), in the central square;

Insects (4 percent) in the right square.

A more detailed account of the types of food ingested and their daily variations is expressed by the hachured columns as follows:

1. Minerals (earth) occasionally ingested.

2. Barks and twigs Leaves

3. Leaves, buds and pith and

4. Flower buds and gums $\}$ twigs

5. Immature fruits

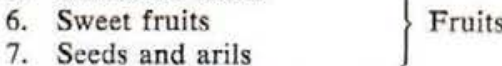

8. Ants, termites, and small arthropods (Orthoptera)

9. Large arthropods (Orthoptera)

10. Eggs, fledgings, and other large prey other 
of Pan troglodytes crosses more than half of the African continent, with three subspecies living in many different environments. Goodall described termite "fishing" behavior by East African chimpanzees. They use a long twig as a "tool" to catch the insects. In several hours of such activity a chimpanzee may obtain a large amount of animal

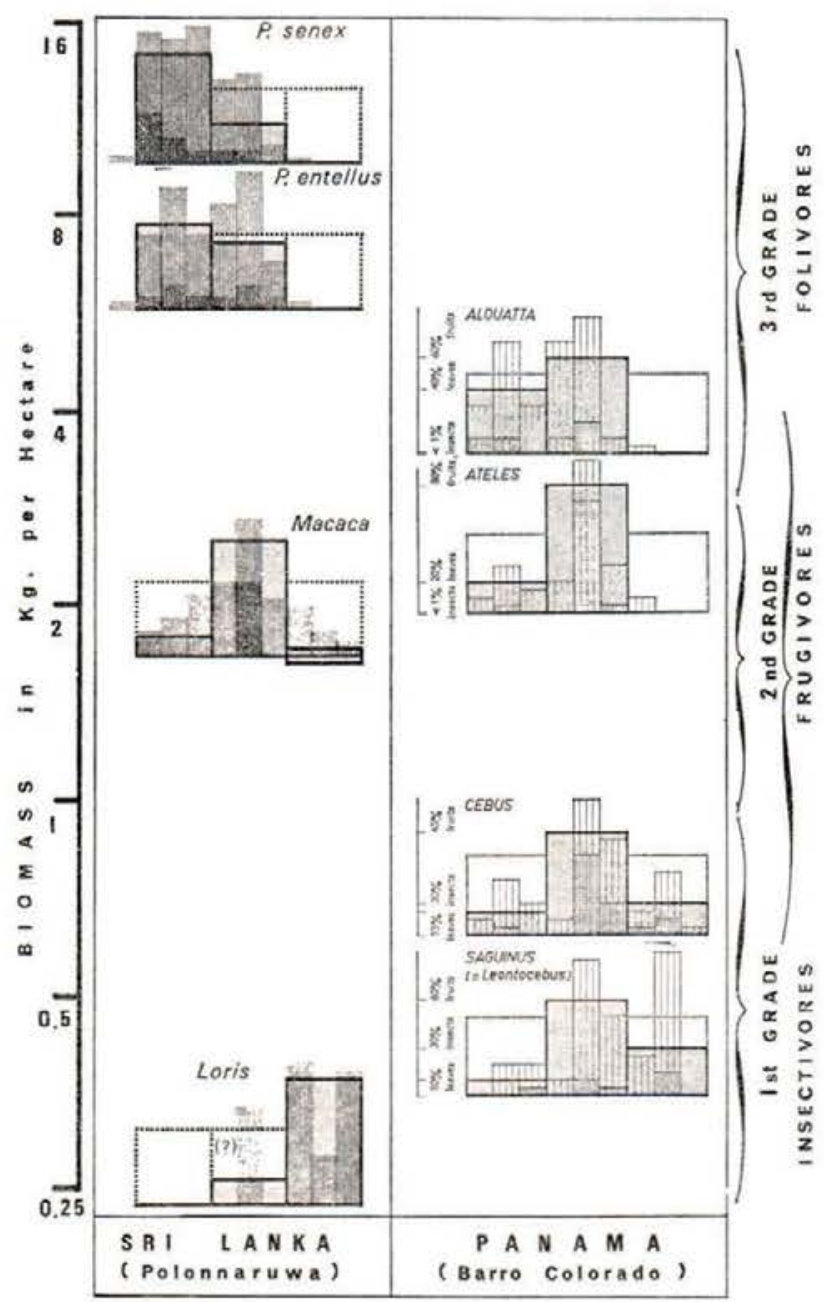

Figure 7b. Relationship between the type of diet and the biomasses of primates in two different field stations.

Each primate species is characterized by its "dietogram" symbolized as in Figure 7a. It level on the present diagram corresponds to its biomass.

It is clear that the different types of diet are directly correlated with the biomass, thus affecting social patterning. protein and fat. Chimpanzees in the rain forest of Gaboon find most of their animal protein in several species of ants' nests. They spend a large part of their time looking for these prey in the manner of gatherers more than hunters. Thus they get a regular supply through gathering. Hunting per contra is an activity of high risk and low return (Lee 1968). In one day we saw 120 grams of insects eaten by chimpanzees (up to 6 percent of the total food amount) gathering the small nests of Macromiscoides aculeatus, one of which contains only 0.2 grams of ants and larvae. Other ants eaten in large quantities are EEcophylla longinoda, Polyrhachis militaris (Plate 5), and Paltothyreus tarsatus. The last species is "fished" with a stick as was described for termites.

To have a regular supply of large quantities of insects, chimpanzees need very wide territories. We have no good data for Gaboon about the size of this area. In the rain forest of East Africa, the densities observed by Reynolds (1965) correspond to a biomass of 1.5 kilograms per hectare, which is somewhat lower than the biomass of the macaque in Polonnaruwa which also feeds on fruits and a small proportion of insects.

Social traditions in local populations of chimpanzees make the use of special techniques possible. An example is the way Panda oleosa or Coula edulis nuts are opened (Rahm 1971). The hard shells are cracked with a branch of hard wood or a heavy stone used as a hammer. This technique is ignored by the chimpanzees living in the rain forest of Gaboon in spite of the local abundance of Coula and Panda. But the variety in the types of food eaten and recognized by the chimpanzees is impressive; we collected 210 specimens of food in the primary forest of Ipassa (Gaboon).

The social unit does not appear to have great cohesion. Sometimes small temporary groups of chimpanzees split or rearrange themselves sometimes in a few hours. It seems that subtle, permanent bonds exist on the larger scale of a "regional population" (Sugiyama 1968). Some fifty individuals are acquainted with each other, maintaining "friendly" interrelations. This type of big "group" lives in a home range much larger than any other territory of frugivorous primates.

The gorilla (Gorilla gorilla), studied by Schaller (1963) in a montane forest, forms smaller social units (six to seventeen individuals) that can fit in the category of "age-graded male groups." One male is dominant and the others become more or less peripheral. The gorilla is a leavesand-fruit eater and there is some similarity with the social patterning of folivorous primates. But territories are among the largest ever seen for primates (twenty-five square kilometers for one group of ten adults). 
This could be explained by the large number of species included in the diet. More than 100 vegetal food species were collected by Schaller. Only the chimpanzee, being more frugivorous, has a wider range (see Suzuki, this volume).

More classical correlations are found in two species of Hylobatidae, in Malaya. The gibbon, Hylobates lar, is predominantly a frugivore while the siamang, Symphalangus syndactylus, eats more leaves and shoots of many vines, including many species of Ficus (Chivers 1972). Both species live in small familial groups maintaining distances by specific calls. But the more folivorous siamang has a territorial area which is only half the size of the territory of the gibbon.

\section{CONCLUSION}

We started this comparative study with a few examples in which the knowledge of precise ecological data allowed comparison of several sympatric primate species. But we were only demonstrating the correlations between the types of social patterning and the resources and habitat use in an supposedly stabilized environment.

Long term mechanisms for regulating population densities were not examined. The most rapid fluctuations may depend on the groups' social structure. In the case of increasing population density, certain species have slight differences in group structure. The males are more aggressive and may kill most of the new-born infants. Eisenberg et al. (1972) showed that this way of limiting the population is not "social pathology" at all because in this case, the "one-male group" is the structure best adapted to the environment. Wynne-Edwards (1962) showed other general mechanisms regulating the population according to available resources but many of them have yet to be verified by ecological observations of primates.

Social patterning is modeled by environmental conditions but it also comes after a long evolution of each systematic group: so we find now different expressions of it. This conclusion is shared by Struhsaker (1969) and Eisenberg et al. (1972). More general laws (Crook and Gartlan 1966) only concern a few precise predators by having a large, ground-living primates adapt against predators by having a large, structured group with a linear hierarchy. The most sophisticated unit with many males is the baboon troop (DeVore and Hall 1965). Among forest-living species, the more terrestrial primates are also the larger groups with ranks of dominance among males. But the occurrence of large, polyspecific groups among arboreal primates of the rain forest (Gautier and Gautier 1969) cannot be explained by the same ecological factor.

Group structure is more directly affected by the way the whole population uses food resources. Similar examples are clear for all leafeating primates: the biomass is high; they are organized in small units ("family" type or "one-male group"); they have narrow territories; and all of them use territorial calls.

In other cases, similarities are not so clear. But some authors speak about folivorous or frugivorous forms or just about arboreal primates without any precise ecological definition. Many field studies concerning the ethology, structure, and composition of primate groups have been carefully carried out, but very few ecological and quantitative data are available, especially on the diet. That is why we quote only a few examples in this text. The last example mentioned (the comparison between the gibbon and the siamang) only refers to the actual time these two species spend feeding on fruits or leaves and not really to the weight eaten. Among Chivers' projects is the collection of complementary quantitative data. In a few years the ecology will be clearly known. The same could be said of the gorilla and of many other primate species. The exact proportions of the different components of the diet must be known at least to elucidate what the impact of the species is on the environment and how it is integrated with it.

With such precise quantitative data we can hope to separate into finer classes the ecological types of primates as follows:

1. The first grade: from typical types of insectivores (Loris, Arctocebus) with a gradation towards diets including fruits and insects (Saguinus, Saimiri) in large proportion (see Figure 7b).

2. The second grade: diets combining insects or other invertebrates and green parts of vegetals, in fairly small proportions, with a main complement of fruits and/or seeds (Cebus, Cercopithecus, Macaca, Papio, Pan, etc.).

3. The third grade: from the frugivores-folivores obtaining their proteins mostly from the leaves (Ateles, Gorilla, Alouatta) toward the more specialized folivores-frugivores with a complex stomach (Presbytis, Colobus) or special caecum (Indri, Lepilemur).

Among the forms of insect-eating primates are the prosimians of continental Africa. For these last species, the ethoecological studies of Charles-Dominique $(1971,1972)$ showed the very exact specializations in the diet of five species living in the rain forest. Charles-Dominique also remarked on the importance of the vegetal gums in the diet of 
certain species (Euoticus elegantulus, Perodicticus potto). This last type of feeding which we are actually investigating might be very different from the frugivore type and more similar to the leaf-eating specialization shown in our third grade.

The classical term omnivore has generally applied to the first or second grade of primate ecological types, including all transitional types. Now it should be avoided, because it is used with different definitions by different authors.

In all these ecological categories, there may be variations in the social patterns of the internal structures of the social units but they are most closely correlated with the mode of sharing local resources.

\section{REFERENCES}

BECK, B. B., R. TUTTLE

1972 "The behavior of gray langurs at a Ceylonese waterhole," in The functional and evolutionary biology of primates. Edited by $\mathrm{R}$. Tuttle, 351-377. Chicago: Aldine-Atherton.

CHARLES-DOMINIQUE, P.

1971 Eco-éthologie des Prosimiens du Gabon. Biologia Gabonica 7(2): 121-228,

1972 Comportement et écologie des Prosimiens nocturnes. Ecologie et vie sociale de Galago demidovii. Zeitschrift für Tierpsychologie, supplement 9:7-41.

CHARLES-DOMINIQUE, P., C. M. HLADIK

1971 Le Lepilemur du sud de Madagascar: écologie, alimentation et vie sociale. La Terre et la Vie 25:3-66.

CHIVERS, D. J.

1972 "The siamang and the gibbon in the Malay peninsula," in Gibbon and siamang. Edited by D. M. Rumbaugh, 103-135. Basel: S. Karger.

CROOK, J. H., J. S. GARTLAN

1966 Evolution of primate societies. Nature 210:1200-1203.

DE VORE, I., K. R. L. HALL

1965 "Baboon ecology," in Primate behavior. Edited by I. DeVore, 20-52. New York: Holt, Rinehart and Winston.

EISENBERG, J. F., R. E. KUEHN

1966 The behavior of Ateles geoffroyi and related species. Smithsonian Miscellaneous Collections 151(8):1-163.

EISENBERG, J. F., G. M. MC KAY

1970 An annotated checklist of the recent mammals of Ceylon with keys to the species. The Ceylon Journal of Science, Biological Sciences 8(2):69-99.
EISENBERG, J. F., N. A. MUCKENHIRN, R. RUDRAN

1972 The relation between ecology and social structures in primates. Science 176:863-874.

GAUTIER, J. P., A. GAUTIER-HION

1969 Les associations polyspécifiques chez les Cercopithecidae du Gabon. La Terre et la Vie 23:164-201.

GOODALL, J.

1965 "Chimpanzees of the Gombe Stream Reserve," in Primate behavior. Edited by I. DeVore, 425-473. New York: Holt, Rinehart and Winston.

HLADIK, A., C. M. HLADIK

1969 Rapports trophiques entre végétation et primates dans la forêt de Barro-Colorado (Panama). La Terre et la Vie 23:25-117.

HLADIK, C. M.

1973 Alimentation et activité d'un groupe de chimpanzés réintroduits en forêt gabonaise. La Terre et la Vie 27:343-413.

HLADIK, C. M., A. HLADIK

1972 Disponibilités alimentaires et domaines vitaux des primates à Ceylan. La Terre et la Vie 26:149-215.

HLADIK, C. M., A. HLADIK, J. BOUSSET, P. VALDEBOUZE, G. VIROBEN, J. DELORT-

LAVAL

1971 Le régime alimentaire des Primates de lî̂le de Barro-Colorado (Panama): résultats des analyses quantitatives. Folia Primatologica $16: 85-122$.

JAY, P.

1965 "The common langur of North India," in Primate behavior. Edited by I. DeVore, 197-249. New York: Holt, Rinehart and Winston.

JOLLY, A.

1966 Lemur behavior. Madagascar field studies. Chicago: The University of Chicago Press.

LEE, R. B.

1968 "What hunters do for a living, or, how to make out on scarce resources," in Man the hunter. Edited by R. B. Lee and I. DeVore, 30-48. Chicago: Aldine.

MANLEY, G.

f.c. "Aspects of the ecology of Presbytis senex."

MARTIN, R. D.

1972 "A preliminary field-study of the Lesser Mouse Lemur," in Behavior and ecology of nocturnal Prosimians. Zeitschrift für Tierpsychologie (supplement) 9:43-89.

MOYNIHAN, M. H.

1964 Some behavior patterns of Platyrrhine monkeys. I. The Night Monkey (Aotus trivirgatus). Smithsonian Miscellaneous Collections 146(5):1-84.

1968 Some behavior patterns of Platyrrhine monkeys. II. Saguinus geoffroyi and some other Tamarins. Smithsonian Miscellaneous Collections. 
OPPENHEIMER, J. R.

1968 "Behavior and ecology of the white-faced monkey Cebus capucinus, on Barro Colorado Island, Canal Zone." Unpublished doctoral dissertation, University of Illinois, Urbana, Illinois.

PETTER, J. J.

1962 Recherches sur l'écologie et l'éthologie des Lémuriens malgaches. Mémoires du Muséum National d'Histoire Naturelle, série A, 27(1):1-146.

i.p. "A study of population density and home range of Indri indri in Madagascar," in Prosimian biology. Edited by R. Martin, G. A Doyle, and A. C. Walker, 75-108. Londen: Duckworth.

PETTER, J. J., C. M. HLADIK

1970 Observations sur le domaine vital et la densité de population de Loris tardigradus dans les forêts de Ceylan. Mammalia 34(3): 394409.

PETTER, J. J., Y. RUMPLER, R. ALBIGNAC

i.p. "Les lémuriens de Madagascar," in Faune de Madagascar. Paris: O.R.S.T.O.M. and C.N.R.S.

POIRIER, F. E.

1970 "The Nilgiri Langur (Presbytis johnii) of South India," in Primate behavior; developments in field and laboratory research. Edited by L. A. Rosenblum, 251-383. New York and London: Academic Press.

RAHM, U.

1971 L'emploi d'outils par les Chimpanzés de l'Ouest de la Côte d'Ivoire. La Terre et la Vie 25:506-509.

REYNOLDS, V., F. REYNOLDS

1965 "Chimpanzees of the Budongo Forest," in Primate behavior. Edited by I. DeVore, 368-424. New York: Holt, Rinehart and Winston.

RIPLEY, $\mathrm{S}$.

1967 "Intertroop encounters among Ceylon gray langurs (Presbytis entellus)," in Social communication among primates. Edited by S. A Altmann, 237-253. Chicago: University of Chicago Press.

1970 "Leaves and leaf monkeys: the social organization of foraging in gray langurs (Presbytis entellus thersistes)," in Old World monkeys. Edited by J. R. Napier and P. H. Napier, 481-509. New York and London: Academic Press.

\section{RUDRAN, R.}

1970 "Aspects of ecology of two subspecies of purple-faced langurs (Presbytis senex)." Unpublished thesis, University of Ceylon, Colombo.

1973 Adult males replacement in one-male troops of purple-faced langurs (Presbytis senex senex) and its effect on population structure. Folia Primatologica 19:166-192.

SCHALLER, G. B.

1963 The mountain gorilla: ecology and behavior. Chicago and London: University of Chicago Press.
SMITH, C. C.

1968 The adaptive nature of social organization in the genus of tree squirrel Tamiasciurus. Ecological Monographs 38:31-63.

SUGIYAMA, Y.

1968 Social organization of chimpanzees in the Budongo Forest, Uganda. Primates 9:225-258.

SUGIYAMA, Y., K. YOSHIBA, M. D. PATHASARATHY

1965 Home range, mating season, maie group and inter-troop relations in Hanuman langurs (Presbytis entellus). Primates 6:73-106.

SUSSMAN, R. W.

1974 "Ecological distinctions in sympatric species of lemur," in Prosimian biology. Edited by R. Martin, G. A. Doyle, and A. C. Walker, 75-108. London: Duckworth.

SUSSMAN, R. W., A. RICHARD

1974 "The role of aggession among diurnal prosimians," in Aggression, territoriality and xenophobia in the primates. Edited by R. L. Holloway, 49-76. New York: Academic Press.

STRUHSAKER, T. T.

1969 Correlates of ecology and social organization among African cercopithecines. Folia Primatologica 11:80-118.

TELEKI, G.

1973 The omnivorous chimpanzee. Scientific American 228(1):32-42. WOODBURN, J.

1968 "An introduction to Hadza ecology," in Man the hunter. Edited by R. B. Lee and I. DeVore, 49-55. Chicago: Aldine.

WYNNE-EDWARDS, v. c.

1962 Animal dispersion in relation to social behaviour. Edinburgh and London: Oliver and Boyd.

Address in 2013 :

\section{Claude Marcel HLADIK}

Directeur de recherche émérite

Eco-Anthropologie et Ethnobiologie

Muséum National d'Histoire Naturelle

4 avenue du Petit Château

91800 Brunoy (France) 